\title{
Heat and Mass Transfer on the Microwave Drying of Rough Rice Grains: An Experimental Analysis
}

\author{
Edna G. Silva ${ }^{1}$, Ricardo S. Gomez ${ }^{2, *(\mathbb{D})}$, Josivanda P. Gomes ${ }^{3}{ }^{\oplus}$, Wilton P. Silva ${ }^{4}{ }^{\oplus}$, Ketinlly Y. N. Porto ${ }^{5}$, \\ Fagno D. Rolim ${ }^{6}$, João E. F. Carmo ${ }^{2}$, Romário O. Andrade ${ }^{2}$, Ivonete B. Santos ${ }^{1}$, Rodrigo A. A. Sousa ${ }^{6}$, \\ Diego D. S. Diniz ${ }^{7}{ }^{\mathbb{D}}$, Marcella M. C. A. Aragão ${ }^{8}$ and Antonio G. B. Lima ${ }^{2}$
}

1 Department of Physics, State University of Paraiba, Campina Grande PB 58429-500, Brazil; dinasansil@yahoo.com.br (E.G.S.); ivoneetebs@gmail.com (I.B.S.)

2 Department of Mechanical Engineering, Federal University of Campina Grande, Campina Grande PB 58429-900, Brazil; jevan.franco@gmail.com (J.E.F.C.); romario_andrade@hotmail.com (R.O.A.); antonio.gilson@ufcg.edu.br (A.G.B.L.)

3 Department of Agricultural Engineering, Federal University of Campina Grande, Campina Grande PB 58429-900, Brazil; josivanda@gmail.com

4 Department of Physics, Federal University of Campina Grande, Campina Grande PB 58429-900, Brazil; wiltonps@uol.com.br

5 Department of Civil Engineering, Federal University of Campina Grande, Campina Grande PB 58429-900, Brazil; yasmynefisio@hotmail.com

6 Teacher Training Center, Federal University of Campina Grande, Cajazeiras PB 58900-000, Brazil; dallino@hotmail.com (F.D.R.); rodrigo.pre@ufcg.edu.br (R.A.A.S.)

7 Department of Engineering, Rural Federal University of Semi-Arid, Caraúbas RN 59780-000, Brazil; diego.diniz@ufersa.edu.br

8 Department of Chemical Engineering, Federal University of Campina Grande, Campina Grande PB 58429-900, Brazil; marcella.may@hotmail.com

check for updates

Citation: Silva, E.G.; Gomez, R.S.; Gomes, J.P.; Silva, W.P.; Porto, K.Y.N.; Rolim, F.D.; Carmo, J.E.F.; Andrade, R.O.; Santos, I.B.; Sousa, R.A.A.; Diniz, D.D.S.; et al. Heat and Mass Transfer on the Microwave Drying of Rough Rice Grains: An Experimental Analysis. Agriculture 2021, 11, 8. https://dx.doi.org/ 10.3390/agriculture11010008

Received: 14 November 2020 Accepted: 21 December 2020 Published: 24 December 2020

Publisher's Note: MDPI stays neutral with regard to jurisdictional claims in published maps and institutional affiliations.

Copyright: () 2020 by the authors. Licensee MDPI, Basel, Switzerland. This article is an open access article distributed under the terms and conditions of the Creative Commons Attribution (CC BY) license (https: / / creativecommons.org / licenses/by/4.0/).
* Correspondence: ricardosoaresgomez@gmail.com; Tel.: +55-83-98893-7991

\begin{abstract}
This work aims to experimentally study the drying of agricultural products using microwaves, with particular reference to grains. Microwave drying experiments were carried out with paddy rice grains in natura (BRSMG Conai variety) for three levels of incident microwave power per mass of fresh grain $(6.27,14.63$ and $22.99 \mathrm{~W} / \mathrm{g}$ ). Results of grain drying and heating kinetics are presented and analyzed. It was verified that the ideal average moisture content for grain storage and marketing, $15 \%$ (d.b.), occurred at $20 \mathrm{~min}(6.27 \mathrm{~W} / \mathrm{g}), 13 \mathrm{~min}(14.63 \mathrm{~W} / \mathrm{g})$ and $7 \mathrm{~min}(22.99 \mathrm{~W} / \mathrm{g})$, and that the equilibrium moisture content of the samples reached $4.4 \%, 2.7 \%$ and $1.9 \%$, at 310,180 and $110 \mathrm{~min}$, for each of the three power levels studied, respectively. The drying with the highest absorbed power caused discoloration of the grains at the end of the drying process.
\end{abstract}

Keywords: drying; microwave; paddy rice; heat; mass; experimental

\section{Introduction}

Microwaves, or high frequency waves, are non-ionizing electromagnetic waves that belong to the range of the electromagnetic spectrum with a wavelength in the range between $1 \mathrm{~mm}$ and $1 \mathrm{~m}$, corresponding to the frequency variation from $300 \mathrm{MHz}$ to $300 \mathrm{GHz}$. These waves are used in locating airplanes and boats, in mobile telephony and in the food industry through defrosting, tempering, freeze drying, baking, drying, heating and reheating tasks.

A microwave energy application system is basically composed of components that generate energy at a certain frequency and conduct it to an applicator or cavity, in which the power can be dissipated in the product when it is heated [1-3].

Electromagnetic waves of the microwave type, like visible light, can be transmitted, reflected or absorbed depending on the exposed material. According to Menezes et al. [4], 
depending on the interaction of the materials with the incident microwave energy, the materials can be classified into three categories, namely: (a) transparent materials (e.g., glass, plastic and ceramics); (b) reflective materials (e.g., metals) and, (c) absorption materials with high dielectric loss (e.g., fruits and vegetables) and mixed absorption (e.g., composites).

The material absorbs microwave energy through two mechanisms: ionic conduction and dipolar rotation [5-7]. Metaxas and Meredith [5] report that, in material drying processes in a microwave oven, the main phenomenon responsible for heating and consequently for the removal of water, is dipolar rotation. Before describing this phenomenon, it is necessary to remember that the water molecule, despite having zero total electric charge, presents itself as an electric dipole, since the center of gravity of the positive charges does not coincide with that of the negative charges. Thus, it is said that the water molecule is polar and, under the action of an external electric field, that same dipole tends to rotate, orienting itself in the direction of the field. The rotation of the dipole encounters resistance, which results in the dissipation of electromagnetic energy from the field in the form of heat, with the consequent increase in temperature.

The microwave drying process has been used as an alternative method of dehydration to obtain high quality dry products, such as fruits, vegetables and grains. The main advantages of microwave drying can be mentioned: high drying rate, energy saving, shorter drying time, high energy efficiency that can be achieved in the decreasing rate period; accumulation of moisture on the surface of the material and the phenomenon of liquid bubbles that prevents it from hardening, reduction in the storage process and rehydration capacity of the dry product, and improvement in the final quality of the dry product, that is, greater retention of aroma, color, hydration and greater porosity [8-11].

Electromagnetic energy in the 915 to $2450 \mathrm{MHz}$ band can be absorbed and converted into heat by materials containing water or other substances such as carbon and organic products $[12,13]$. Since waves can penetrate directly into the material, heating is volumetric and provides rapid and uniform heating throughout the product. The rapid absorption of energy by water molecules causes the rapid evaporation of water and higher drying rate of the food. Microwave-dried products have better results in terms of rehydration characteristics $[14,15]$.

Heating food using microwaves is a promising phenomenon and the success of these applications depends on understanding the interaction between microwaves and food, and the ability to predict and provide a desired heating pattern in foods using specific applications [16]. However, the volumetric heating of microwave energy can create a film of water on the surface due to the lower temperature of the ambient air surrounding the product and, when treated improperly, can lead to the electrical conduction of the surface, which can damage the product [17].

The heating of materials by means of microwave energy has had great industrial prominence, since this process has a series of advantages over conventional heating methods. Khodifad and Dhamsaniya [18] report that in the microwave drying process there is a rapid rise in temperature (volumetric heating) inside the product due to the mechanisms of ionic polarization and dipolar rotation [19]. In the conventional heating process, the energy is transferred to the food by conduction, convection and radiation from the surface of contact with the heat source, thus having heat penetration from the surface into the product, providing a long drying time. This is the main disadvantage in using the conventional process in relation to the microwave drying process of biological products.

According to the literature, the microwave drying process has been applied to several agricultural products, such as: American ginseng roots [20], rice [21,22], maize [23], banana [13], mushroom [24], kiwi [25], orange [26], pear [27], wheat grain [28], apple [29], parsley [9], carrot [30], potato [31,32], grapes [15], tomatoes [33,34], coffee [35], spinach [36], raspberries [37], Kumquat [38], among others.

The application of microwaves in drying provides the material with an operation without direct contact with the heat source, enabling a more sanitary operation, with minimal risk of contamination and, preserving the physical structure that guarantees 
quality to the product. Oomah et al. [39] and Cabral et al. [40] emphasize this view of microwave drying.

Several factors affect the microwave drying and heating processes, with a direct relationship between the mass and the amount of microwave energy being absorbed. This energy is continuously applied until the desired heating is reached. The domestic microwave oven provides uniform heating by moving the product through the microwave field. This equipment is programmed to receive a critical mass of about $250 \mathrm{~mL}$ of water and a maximum power of $1 \mathrm{~kW}$, since lower load masses may damage the magnetron and impair the equipment's efficiency [41].

Several studies are reported in the literature that discuss the great importance of the use of microwaves for heating and drying purposes, for example, Tang and Resurreccion Jr. [42], Feng et al. [43], Laguerre et al. [44], Almeida et al. [41], and Liu et al. [45].

Rice is a herbaceous plant belonging to the grass family. The species of the genus Oryza are hydrophilic, adapt to the most varied environmental conditions, and are distributed in almost all continents, including wild species, natural hybrids, commercial cultivars, and other traditional varieties [46]. The chemical composition of rice varies depending on the conditions of pre-storage, storage, variety and processing system [47]. The first one, the husk, represents $22 \%$ of the volume of each grain. The germ (or bran) makes up $8 \%$ of each grain, being the most nutritious part. The bran is considered a by-product obtained in the polishing of the peeled grain, consisting of pericarp, integument, aleurone, germ and superficial portions and/or small particles of starchy endosperm. The grain or kernels is the most consumed part of the cereal and represents about $70 \%$ of it [48]. The paddy rice contains, on average, 6.7 to $8.3 \%$ protein, 2.1 to $2.7 \%$ lipids, 3.4 to $6.0 \%$ ash and 70.5 to $84.2 \%$ carbohydrates.

Among the factors that influence the quality of the rice grain, the following can be highlighted: the varietal characteristics, the conditions of development of the culture, the handling and the climatic conditions, the season and the conditions of harvest, drying methods and system, storage systems, conservation methods, processes and industrial processing of grains.

Walter et al. [49] emphasize that, increasingly, rice stands out not only as one of the main foods for the population, but also as a quality food, which can help maintain health, and the production of this cereal and the continuity of research. In addition, there is also the increasing demand from national consumers for higher product quality, forcing the production and research sectors to be increasingly efficient.

Despite all the productive capacity in Brazil, much remains to be done to better meet the demands of the national and international markets regarding the quality of grains, making the practices adopted from harvest to storage as appropriate as possible [50].

Agricultural products such as rice, corn and soybeans are consumed on a large scale worldwide due to their high nutritional value. Thus, with the use of these products on a large scale, there is a growing concern with storage and conservation and, to maintain the high quality of these materials. Further, it is necessary a priori that the product be harvested healthy and in advance, in order to minimize the losses caused in the field.

After harvesting, the entire harvest must be destined for storage. Generally, when produced on a large scale, the products are stored in bins. For the use of these storage units, agricultural products must meet a safety margin regarding moisture, since moisture combined with high temperatures intensifies the deterioration process of stored grains [51].

The less time that elapses between harvesting and drying, the less damage will be done to the product. Grain deterioration occurs due to the high-water content at harvest, and among the techniques involved in preserving the desirable qualities of products of plant origin, drying is one of the most important operations [52].

Physiologically mature, freshly harvested paddy rice can contain moisture between 18 and $28 \%$ on a wet basis (w.b.). Through artificial drying, the excess water from the grain is removed to appropriate limits, minimizing metabolic changes and damage by the action of insects and fungi [53]. In order to obtain high quality of rice and avoid problems in storage, 
the moisture content of the product must be reduced to 12 to $14 \%$ on a wet basis, whatever the drying method used. It is worth noting that when rice is harvested too moist or too late, with low moisture content, the productivity and quality of the grains are impaired. In this context, the drying of rice grains has been carried out using warm air (convective drying), and there are few works using other techniques, such as, for example, microwaves.

In addition to this research, this work aims to experimentally study the drying of agricultural products by microwave, with particular reference to rough rice (paddy rice). The innovative aspects are evidenced in the wide discussion about drying with microwaves, in the type of material studied, in the measurements of grain temperature throughout the process, and in the analysis of the quality of the post-drying product.

\section{Methodology}

\subsection{The Geometry and Physical Problem}

The raw material under analysis is the unprocessed paddy rice grain (BRSMG Conai variety) from the Florestan Fernandes settlement, located in the city of Goiana, Pernambuco state, Brazil. For the experiments, approximately $32 \mathrm{~g}$ of rice grains were used. The BRSMG Conai variety was obtained from the crossing between the BRS Confiança and Aimoré varieties by Embrapa Arroz e Feijão de Goiás (Brazil), in 1998. This crossing enabled the transformation of two varieties of rice grains into a single variety with the characteristics: precocity (Aymoré), long fine grain (Confiança), lodging resistance, greater drought tolerance and greater grain productivity [54].

After harvesting, the rice was stored and immediately transported in an airtight bag to the laboratory, to carry out the experiments. The following equipment was used in the drying experiments:

(a) Méssen digital caliper (São Paulo, SP, Brazil), with $0.01 \mathrm{~mm}$ precision. Used to measure the dimensions of rice grains (length, thickness and width);

(b) Digital electronic scale, Marte model AL 500 (São Paulo, SP, Brazil) with accuracy of $0.001 \mathrm{~g}$. Used for weighing samples of rice husk samples;

(c) Household microwave oven, Electrolux model MEP37 (Stockholm, Sweden), with the following characteristics: capacity 27 L, power key, weight/portion key, height 283 $\times$ width $486 \times$ depth $405 \mathrm{~mm}$, voltage $220 \mathrm{~V}$, electric current $6.5 \mathrm{~A}, 54 \%$ efficiency, microwave frequency $2450 \mathrm{MHz}$ and frequency $60 \mathrm{~Hz}$. Used for heating and drying rice grain samples.

(d) Oven with air mechanical circulation, FANEM model 320 E (Guarulhos, SP, Brazil) with general temperature controller. Used to determine the dry matter of rice grains, at $105^{\circ} \mathrm{C}$ for $24 \mathrm{~h}$;

(e) Infrared thermometer, Instrutherm model TI-890 (São Paulo, SP, Brazil), with laser sight and scale from 50 to $1000{ }^{\circ} \mathrm{C}$. Used to measure the surface temperature of the rice grain;

(f) Thermohygrometer, ICEL model HT-208 (Manaus, AM, Brazil). Used to obtain the temperature and relative humidity of the ambient air outside of the household microwave oven and oven with air mechanical circulation during the drying process;

(g) Glass Petri dish with diameter $60 \times 15 \mathrm{~mm}$, manufactured by Pyrex (Corning, NY, USA) and used as a container for the samples.

\subsection{Experimental Procedures}

\subsubsection{Drying}

The microwave drying process was carried out with three samples of approximately $10 \mathrm{~g}$ of rice grains for each sample, and set time for three power levels $(10,20$ and $30 \%$ of the nominal power) in the microwave oven, previously established. The three levels of nominal power supplied by the microwave oven per mass of fresh grain $(6.27 \mathrm{~W} / \mathrm{g}, 14.63 \mathrm{~W} / \mathrm{g}$ and $22.99 \mathrm{~W} / \mathrm{g}$ ) were obtained experimentally using the methodology of distilled water heating. For this, $600 \mathrm{~mL}$ of liquid water was placed in a plastic container and the temperature of the liquid was measured. Then, the container was placed in the center of the microwave 
oven. After closing the equipment door, the power and the process time were adjusted. After the established time, a water temperature measurement was made. From this, using the energy balance, the power supplied by the device at each power level was obtained.

In the preparation of the samples, the following steps were performed: (a) measurements of the dimensions (length, width and thickness) of the rice grains; (b) determination of the mass of the Petri dish and the sample (Petri dish + grains); (c) measuring the surface temperature of the sample, and (d) positioning the sample in the center of the oven turntable.

After these steps, the oven door is closed and the power and set time are adjusted, starting the drying process. At the end of the time, data concerning temperature measurements on the surface of the grains and the mass of the sample are collected. This procedure was carried out, for different previously defined time intervals. For sample 1, 20 repetitions were performed, in a time interval of $1 \mathrm{~min}, 10$ repetitions in $5 \mathrm{~min}$ intervals and later, repetitions in 10 min intervals. The drying process was completed, when the sample mass showed two values approximately equal $( \pm 0.01 \mathrm{~g})$, indicating stability and, consequently the end of evaporation.

Once the balance was reached, the sample was placed in the oven with air mechanical circulation, previously set at $105^{\circ} \mathrm{C}$ and for $24 \mathrm{~h}$ to obtain dry matter. Then, mass and surface temperature measurements were made on the grain. Room temperature and relative humidity were also recorded throughout the drying process.

Figure 1 illustrates the rice grain samples for the drying process inside the domestic microwave oven.

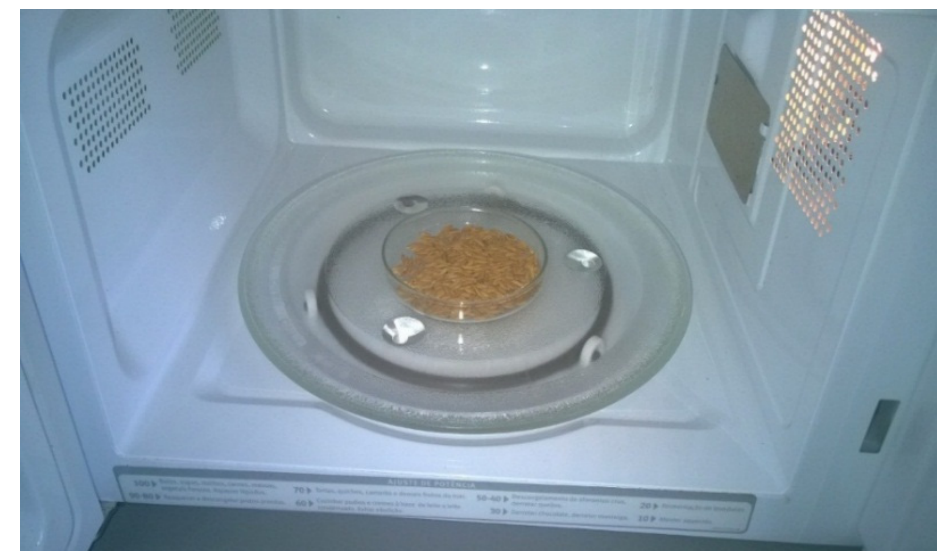

Figure 1. Sample positioned in the microwave oven to start drying.

\subsubsection{Auxiliary Parameters}

After finishing the drying process of the rice grain samples, it was necessary to perform complementary calculations to obtain the parameters that will be used in the heating and drying kinetics.

\section{- Water mass}

The calculation of the amount of water $\left(m_{\text {water }}\right)$ of the rice grain sample, in the measurement time, was made based on the value of the sample mass (m) and the dry sample mass $\left(\mathrm{m}_{\mathrm{s}}\right)$, as follows:

$$
\mathrm{m}_{\mathrm{water}}=\mathrm{m}-\mathrm{m}_{\mathrm{s}} \text {. }
$$

\section{- Moisture content}


The calculation of the moisture content in wet basis $\left(\overline{\mathrm{M}}_{\mathrm{w} . \mathrm{b} .}\right)$ of paddy rice grains, at the measurement time, was made based on the value of the water mass $\left(\mathrm{m}_{\text {water }}\right)$ and the mass of wet grains $\left(\mathrm{m}=\mathrm{m}_{\mathrm{water}}+\mathrm{m}_{\mathrm{s}}\right)$, as follows:

$$
\overline{\mathrm{M}}_{\mathrm{w} \cdot \mathrm{b} .}=\frac{\mathrm{m}_{\mathrm{water}}}{\left(\mathrm{m}_{\text {water }}+\mathrm{m}_{\mathrm{s}}\right)}
$$

The dry matter moisture content $\left(\overline{\mathrm{M}}_{\mathrm{d} . \mathrm{b}}\right.$. $)$ of the sample at each measurement time was calculated based on the value of the water mass of the rice grains $\left(\mathrm{m}_{\mathrm{water}}\right)$ and the mass of the rice grains completely dry $\left(\mathrm{m}_{\mathrm{s}}\right)$, as follows:

$$
\overline{\mathrm{M}}_{\mathrm{d} . \mathrm{b} .}=\frac{\mathrm{m}_{\mathrm{water}}}{\mathrm{m}_{\mathrm{s}}}
$$

The calculation of the average dimensionless moisture content $(\bar{M})$, of the rice grain sample at the time of measurement, was made based on the value of the average moisture content $(\overline{\mathrm{M}})$, the initial moisture content $\left(\overline{\mathrm{M}}_{0}\right)$ and equilibrium moisture content $\left(\overline{\mathrm{M}}_{\mathrm{e}}\right)$ on a dry basis (d.b.), as follows:

$$
\overline{\mathrm{M}}^{*}=\frac{\overline{\mathrm{M}}-\overline{\mathrm{M}}_{\mathrm{e}}}{\overline{\mathrm{M}}_{0}-\overline{\mathrm{M}}_{\mathrm{e}}} .
$$

\section{- Total volume and total surface area of rice grain}

In this research, the paddy rice grain was considered as an ellipsoid of revolution. Figure 2 illustrates a comparison between the geometries of the rice grain and the ellipsoid of revolution (prolate spheroid). To determine the volume and the total surface area of the grain, measurements were made of the dimensions of length or major axis (A), width or medium axis (B) and width or minor axis (C) of 36 grains of rice before drying, in each sample. After digitizing the measured values, the arithmetic mean of the different values of length (A), and the arithmetic mean of the different values of the sum of the dimensions of the major and minor axis of the grain $(B+C)$ were performed. Finally, dividing each result by 2 , the values of the major and minor semi-axes of the prolate spheroid were obtained, named, respectively, $\mathrm{L}_{2}$ and $\mathrm{L}_{1}$ (Figure 2).

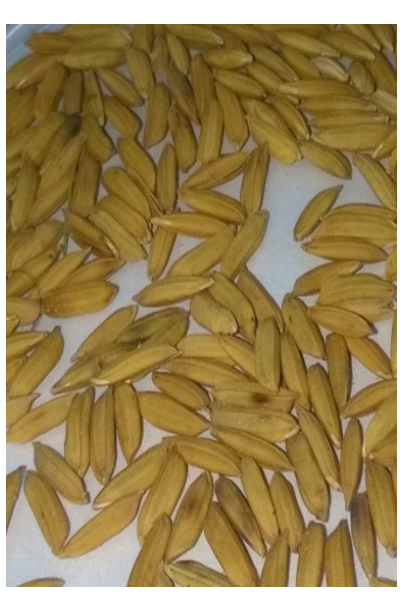

(a) Paddy rice grains

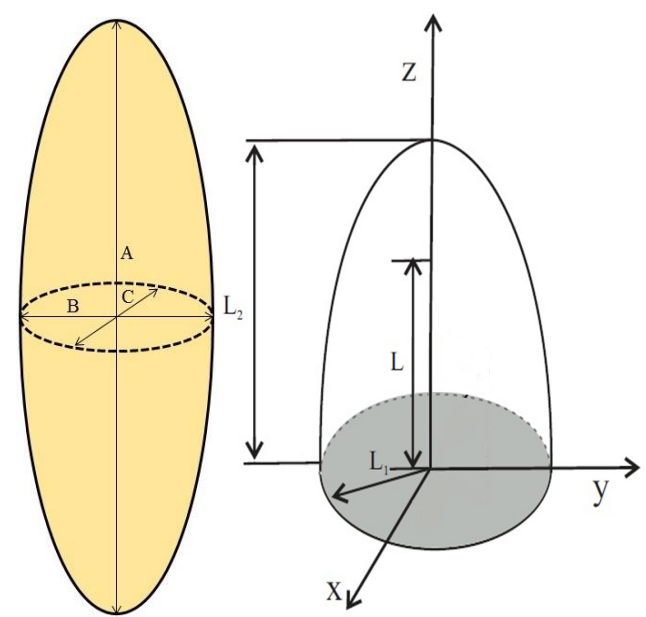

(b) Ellipsoid of revolution

Figure 2. Comparison of the shape of the paddy rice grain (a) with the revolution ellipsoid (b). 
To obtain the total volume of the ellipsoid of revolution (prolate spheroid), the following equation was considered:

$$
\mathrm{V}_{\mathrm{t}}=\frac{4 \pi}{3}\left(\mathrm{~L}_{2}\right)\left(\mathrm{L}_{1}\right)^{2}
$$

In addition, according to Pólya and Szegö [55], the total surface area of the prolate spheroid is given by:

$$
\mathrm{S}_{\mathrm{t}}=2 \pi\left(\mathrm{L}_{1}\right)_{\mathrm{t}}\left(\mathrm{L}_{2}\right)_{\mathrm{t}}\left\{\frac{\left(\mathrm{L}_{1}\right)_{\mathrm{t}}}{\left(\mathrm{L}_{2}\right)_{\mathrm{t}}}+\frac{\operatorname{arcsen}\left[\sqrt{1-\left[\left(\frac{\left(\mathrm{L}_{1}\right)_{\mathrm{t}}}{\left(\mathrm{L}_{2}\right)_{\mathrm{t}}}\right)^{2}\right]}\right]}{\sqrt{1-\left[\left(\frac{\left(\mathrm{L}_{1}\right)_{\mathrm{t}}}{\left(\mathrm{L}_{2}\right)_{\mathrm{t}}}\right)^{2}\right]}}\right\} .
$$

The prolate spheroid has the following specificities:

$$
\mathrm{L}=\sqrt{\mathrm{L}_{2}^{2}-\mathrm{L}_{1}^{2}} \text { and } \mathrm{L}_{2}>\mathrm{L}_{1} .
$$

where $L$ is the focal length of the ellipse.

\section{Results and Discussion}

\subsection{Mass Loss of Rice Grains during Drying}

Tables 1 and 2 illustrate the initial and final results of the average moisture content, the microwave power supplied by the oven and the total drying process time for each experiment performed. The terms in this table are broken down as: $\mathrm{P}_{\text {sup }}$ (microwave power supplied by the oven), $\mathrm{m}_{0}$ (initial mass of the grain sample), $\mathrm{m}_{\mathrm{s}}$ (dry mass of a grain), $\mathrm{M}_{0}$ (initial moisture content on dry basis or on wet basis), $\mathrm{M}_{\mathrm{eq}}$ (equilibrium moisture content on dry basis or wet basis), $\mathrm{T}_{0}$ (initial temperature on the grain surface), $\mathrm{T}_{\mathrm{f}}$ (final temperature on the grain surface) and $t$ is the total drying time. To obtain the values of the microwave power supplied by the oven, the experimental supplied microwave power was divided by the number of grains in each sample. The result of the dry mass obtained after $24 \mathrm{~h}$ in an

\begin{tabular}{|c|c|c|c|c|c|c|}
\hline \multirow{2}{*}{ Test } & \multirow{2}{*}{$\begin{array}{l}P_{\text {sup }} \\
(\mathrm{W} / \mathrm{g})\end{array}$} & \multicolumn{4}{|c|}{ Drying Parameters of Rice Grains } & \multirow{2}{*}{$\begin{array}{c}t \\
(\min )\end{array}$} \\
\hline & & $\mathbf{m}_{0}(\mathrm{~g})$ & $\mathrm{m}_{\mathrm{s}}(\mathrm{g})$ & $\mathrm{T}_{0}\left({ }^{\circ} \mathrm{C}\right)$ & $\mathrm{T}_{\mathrm{f}}\left({ }^{\circ} \mathrm{C}\right)$ & \\
\hline 1 & 6.27 & $\begin{array}{c}10.01 \pm \\
0.161\end{array}$ & $\begin{array}{c}0.025 \pm \\
0.0013\end{array}$ & $30.6 \pm 0.53$ & $74.5 \pm 1.03$ & 310 \\
\hline 2 & 14.63 & $\begin{array}{c}10.02 \pm \\
0.153\end{array}$ & $\begin{array}{c}0.027 \pm \\
0.0016\end{array}$ & $30.7 \pm 0.72$ & $97.1 \pm 1.53$ & 180 \\
\hline 3 & 22.99 & $\begin{array}{c}10.01 \pm \\
0.172\end{array}$ & $\begin{array}{c}0.025 \pm \\
0.0010\end{array}$ & $28.8 \pm 0.43$ & $\begin{array}{c}130.0 \pm \\
1.42\end{array}$ & 110 \\
\hline
\end{tabular}
oven was also divided by the number of grains.

Table 1. Supplied microwave power, drying parameters and total drying time.

Table 2. Moisture content of the sample at the beginning and final of the drying process.

\begin{tabular}{ccccc}
\hline \multirow{2}{*}{ Test } & \multicolumn{4}{c}{ Drying Parameters of Rice Grains } \\
\cline { 2 - 5 } & $\mathbf{M}_{0}$ (d.b.) & $\mathbf{M}_{\mathbf{e}}$ (d.b.) & $\mathbf{M}_{0}$ (w.b.) & $\mathbf{M}_{\mathbf{e}}$ (w.b) \\
\hline 1 & $0.228 \pm 0.0016$ & $0.044 \pm 0.0010$ & $0.186 \pm 0.0016$ & $0.042 \pm 0.0010$ \\
2 & $0.240 \pm 0.0022$ & $0.027 \pm 0.0011$ & $0.194 \pm 0.0022$ & $0.026 \pm 0.0011$ \\
3 & $0.245 \pm 0.0018$ & $0.019 \pm 0.0009$ & $0.197 \pm 0.0018$ & $0.018 \pm 0.0009$ \\
\hline
\end{tabular}

Table 3 illustrates the arithmetic mean of the dimensions (A, B and C) of 36 grains of paddy rice; the values of the minor semi-axis $\left(\mathrm{L}_{1}\right)$ and of the major semi-axis $\left(\mathrm{L}_{2}\right)$, assuming the geometry of the grain as a prolate spheroid; the total volume $\left(\mathrm{V}_{t}\right)$ and the total surface area $\left(\mathrm{S}_{\mathrm{t}}\right)$ of the rice grain, and the total number of grains $\left(\mathrm{N}_{\mathrm{t}}\right)$ corresponding to each test. 
Table 3. Dimensional data, volume and surface area and total number of paddy rice grains before microwave drying.

\begin{tabular}{|c|c|c|c|c|c|c|c|c|}
\hline \multirow[t]{2}{*}{ Test } & \multirow[t]{2}{*}{$\mathbf{N}_{\mathrm{t}}$} & \multicolumn{7}{|c|}{ Geometric Parameters of Paddy Rice Grains } \\
\hline & & $A(\mathrm{~mm})$ & B (mm) & $\mathrm{C}(\mathrm{mm})$ & $\mathbf{L}_{1}(\mathrm{~mm})$ & $\mathrm{L}_{2}(\mathrm{~mm})$ & $V_{t}\left(\mathrm{~mm}^{3}\right)$ & $\mathrm{S}_{\mathrm{t}}\left(\mathrm{mm}^{2}\right)$ \\
\hline 1 & 327 & $\begin{array}{c}9.79 \pm \\
0.82\end{array}$ & $\begin{array}{c}2.47 \pm \\
0.27\end{array}$ & $\begin{array}{c}1.98 \pm \\
0.32\end{array}$ & 1.112 & 4.895 & 25.354 & 54.89 \\
\hline 2 & 298 & $\begin{array}{c}9.85 \pm \\
0.76\end{array}$ & $\begin{array}{c}2.45 \pm \\
0.18\end{array}$ & $\begin{array}{c}1.92 \pm \\
0.25\end{array}$ & 1.092 & 4.925 & 24.600 & 54.18 \\
\hline 3 & 331 & $\begin{array}{c}9.37 \pm \\
0.87\end{array}$ & $\begin{array}{c}2.45 \pm \\
0.23\end{array}$ & $\begin{array}{c}1.93 \pm \\
0.21\end{array}$ & 1.095 & 4.685 & 23.530 & 51.79 \\
\hline
\end{tabular}

Silva [48], using rice grain in natura (BRSMG Conai variety) in fixed bed convective drying (oven with forced air circulation) at temperatures of 50,60 and $70{ }^{\circ} \mathrm{C}$ obtained the percentages of the initial average moisture content (17.0, 34.5 and $36.3 \%$ w.b.), percentages of the average moisture content in the balance $(0.54,0.44$ and $0.1 \%)$, and final drying time (1260, 960 and $840 \mathrm{~min})$, respectively. Comparing the results presented in Table 1 with those reported by Silva [48], it is observed that in the two drying methods used, the increase in temperature inside the grains provided increases in the drying rate with reduction in the final time of the process and in the equilibrium moisture content.

Figure 3 illustrates the values of the average moisture content, on a dry basis, as a function of the process time, with adjustment of 10,20 and $30 \%$ of the maximum power of the microwave oven. The warm, low and defrost power levels were established for the sample 1, sample 2, and sample 3, respectively, according to the characteristic of the microwave oven used. These figures show the influence the effect caused by the different powers of the microwave oven applied in the drying process. In this figure, it can be seen that there is a significant reduction in the final drying time of the sample 3 , due to the greater applied microwave power and the greater amount of microwave energy absorbed by the grains. It is easy to see that the highest drying rate has occurred when a higher microwave power has been used.

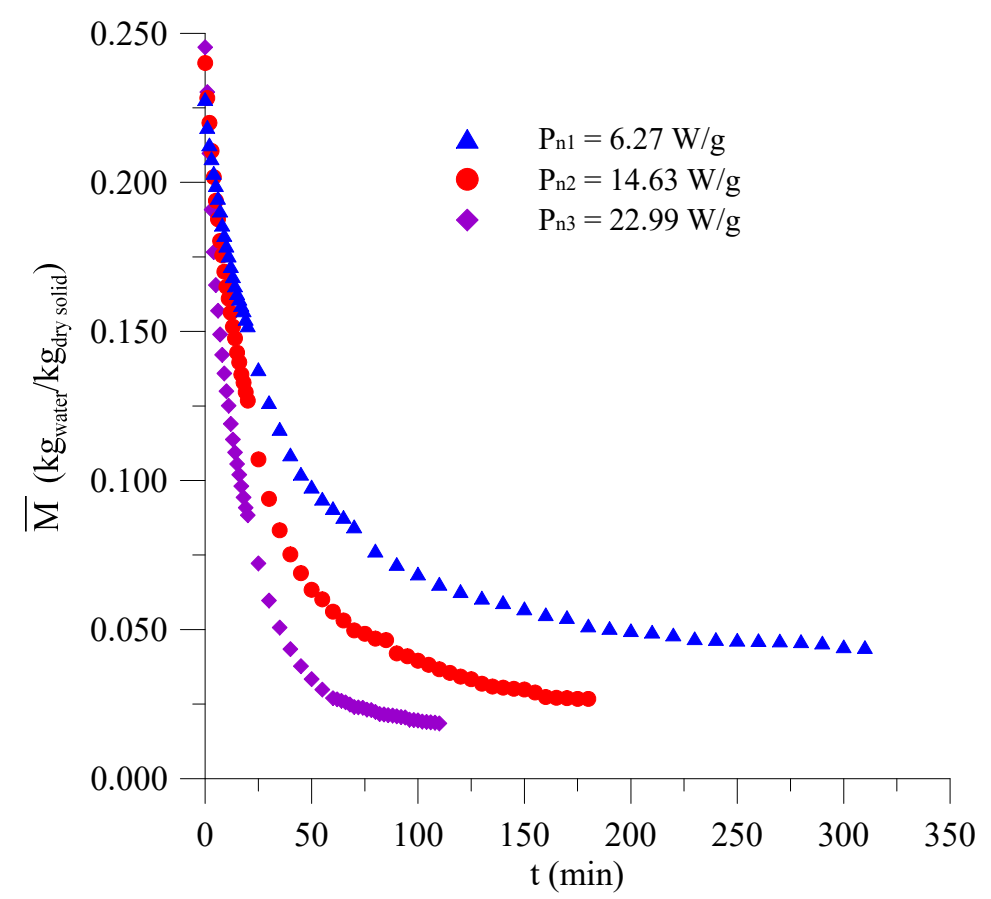

Figure 3. Effect of the supplied microwave power on the average moisture content of rice grains during the drying process.

Upon analyzing Figure 3, it appears that in the first 20 min of the drying process 
there was a rapid decrease in the average moisture content of the paddy rice grains. At this elapsed time, the average moisture content of the material is about $66.6 \%, 52.9 \%$ and $35.9 \%$ of the initial moisture content, for the microwave powers of $6.27 \mathrm{~W} / \mathrm{g}, 14.63 \mathrm{~W} / \mathrm{g}$ and $22.99 \mathrm{~W} / \mathrm{g}$, respectively. The ideal average moisture content for grain storage and marketing, $15 \%$ (d.b.), occurred at different times in the samples, for each of the three power levels studied. The drying process is completed when the samples reached its equilibrium moisture content. Table 4 summarizes some important drying data obtained during the process.

Table 4. Moisture content of the rice grains at the different moments of drying.

\begin{tabular}{ccccccc}
\hline \multirow{2}{*}{ Test } & \multicolumn{6}{c}{ Drying Parameters of Rice Grains } \\
& $\mathbf{t}$ (min) & $\mathbf{M}$ & $\mathbf{t}(\mathbf{m i n})$ & $\mathbf{M}$ & $\mathbf{t}$ (min) & $\mathbf{M}_{\mathbf{e}}$ (d.b.) \\
\hline 1 & 20 & $15.2 \pm 0.21$ & 20 & 15.0 & 310 & $4.4 \pm 0.10$ \\
2 & 20 & $12.7 \pm 0.17$ & 13 & 15.0 & 180 & $2.7 \pm 0.11$ \\
3 & 20 & $8.8 \pm 0.12$ & 7 & 15.0 & 110 & $1.9 \pm 0.09$ \\
\hline
\end{tabular}

Figure 4 illustrates the temporal variations of the drying rates during the microwave drying process of paddy rice grain for the three levels of power supplied by the oven. From the analysis of this figure, it is observed the occurrence of a period of decreasing drying rate throughout the process. At the beginning of the process, the drying rate is more intense and, after $20 \mathrm{~min}$, it slows down until it stabilizes after $60 \mathrm{~min}$. Furthermore, higher drying rates are observed in the higher supplied microwave powers.

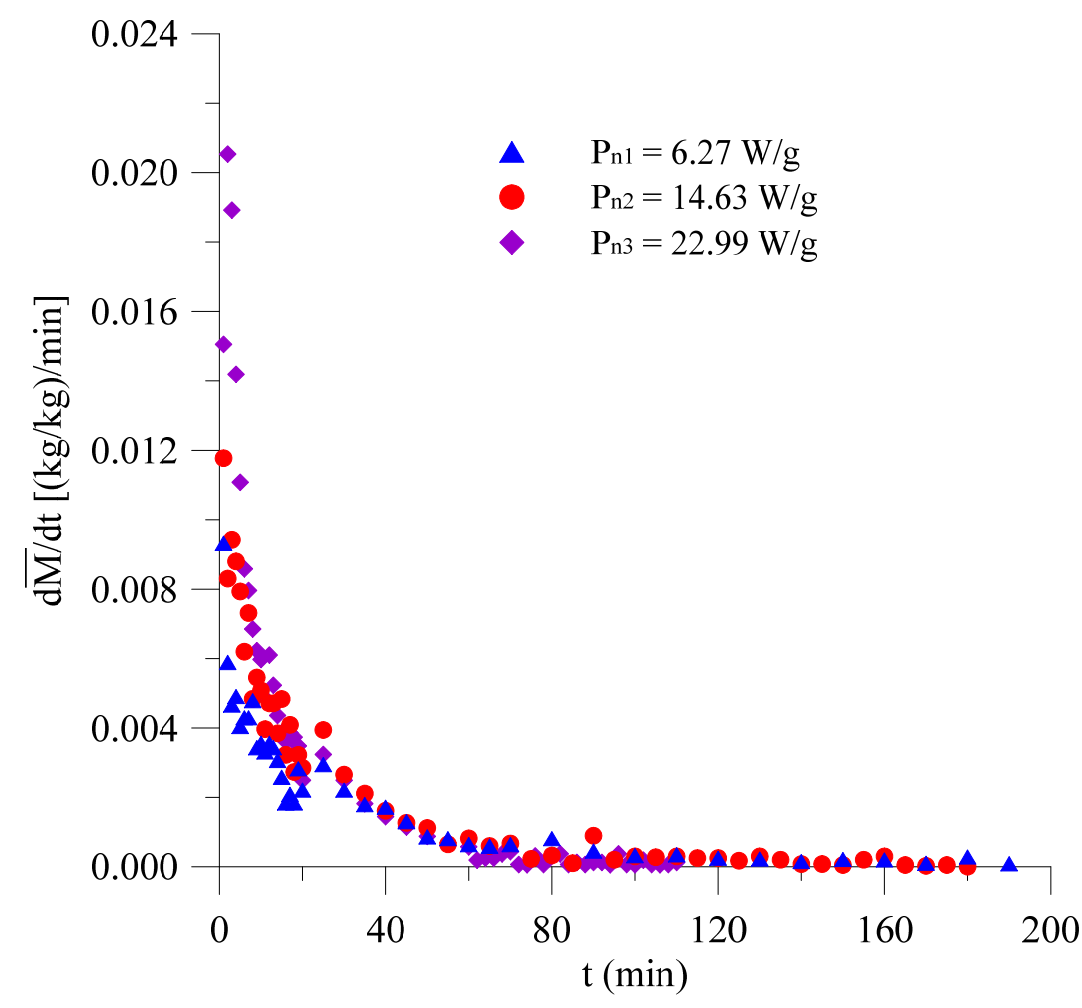

Figure 4. Drying rate of rice grains for different microwave powers. 
Figure 5 on the other hand, illustrates the temporal evolution of the dimensionless moisture content of the paddy rice grains submitted to the microwave drying process, for three microwave powers supplied by the oven. There is clearly a faster drying of the sample used in test 3 , due to the higher initial average moisture content and greater applied microwave power, a consequence of the greater amount of microwave power absorbed by the grains. Further, it is easy to check the drying time required for the material to reach the hygroscopic balance condition. The final drying time for sample 1 is almost three times greater than the drying time for sample 3 . We state that these values are independent of the initial and equilibrium moisture content of the rice grain.

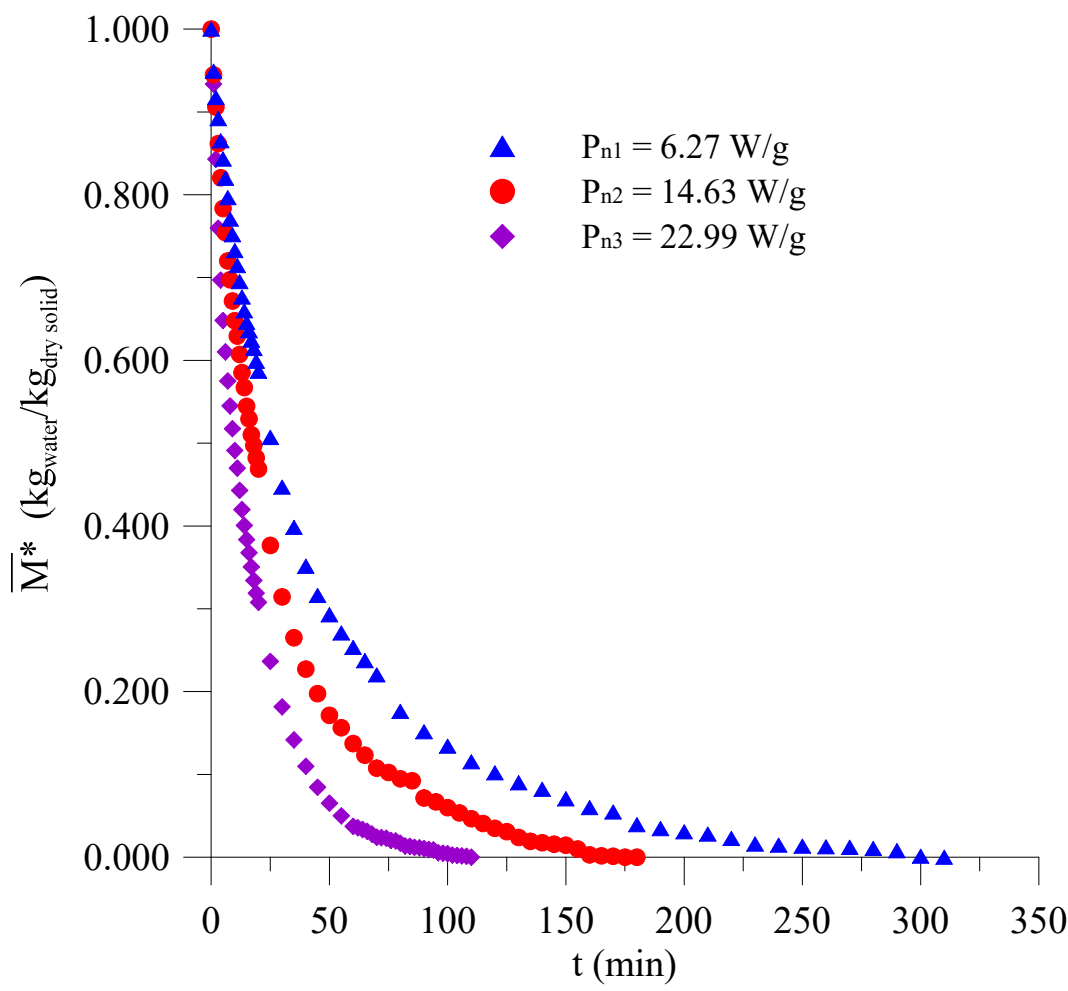

Figure 5. Average dimensionless moisture content of the paddy rice as a function of microwave drying time.

\subsection{Heating of Rice Grains during Drying}

Microwave heating is very fast and widely used, but depending on the body shape its non-uniformity has been the subject of study. Figure 6 illustrates the transient behavior of temperature on the surface of paddy rice grains, measured in the three samples, for the supplied microwave power. In the three cases analyzed, a rapid rise in temperature is observed at the beginning of the drying process due to the supplied microwave powers $\left(P_{n 1}=6.27 \mathrm{~W} / \mathrm{g}, \mathrm{P}_{\mathrm{n} 2}=14.63 \mathrm{~W} / \mathrm{g}\right.$ and $\left.\mathrm{P}_{\mathrm{n} 3}=22.99 \mathrm{~W} / \mathrm{g}\right)$ with a tendency to stabilize at the end of the process. In samples 1,2 and 3 , the temperatures on the surface of the rice grains reached the maximum values of $74.5^{\circ} \mathrm{C}, 95.2^{\circ} \mathrm{C}$ and $112.0^{\circ} \mathrm{C}$, respectively. Further, it can be seen that the increase in the microwave power absorbed by the grains caused a decrease in the total heating time. 


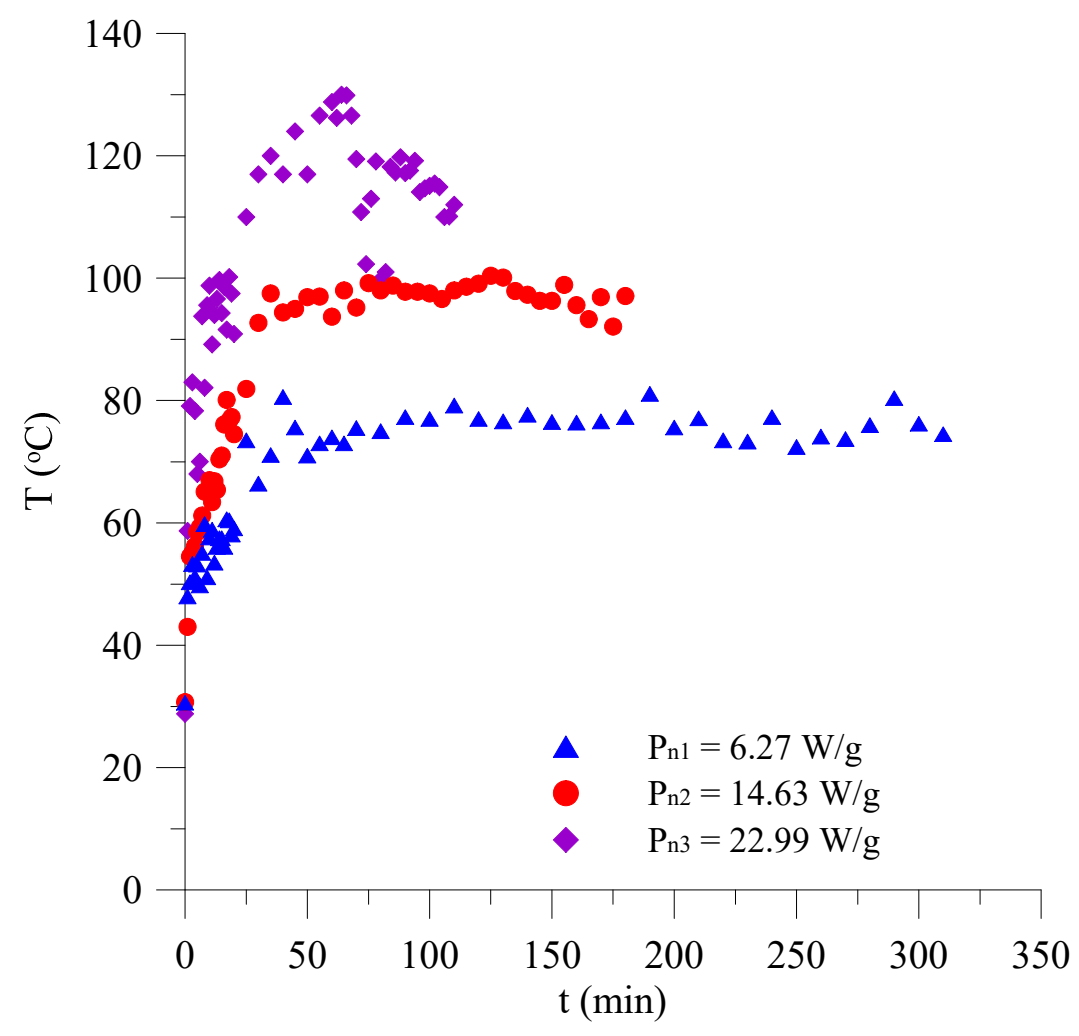

Figure 6. Effect of the supplied microwave power on the surface temperature of paddy rice grains during the drying process.

\subsection{Quality Evaluation of Rice Grains before and after Drying}

Figures 7 and 8 illustrate the physical structure of paddy rice grains, of the samples 1,2 and 3 , before and after the drying process in a domestic microwave oven, and drying in an oven with forced air circulation at $105^{\circ} \mathrm{C}$ for $24 \mathrm{~h}$ to obtain dry matter. From a qualitative analysis of these figures, it can be seen that there are minor physical damages to the final structure of the rice grains after the drying process.

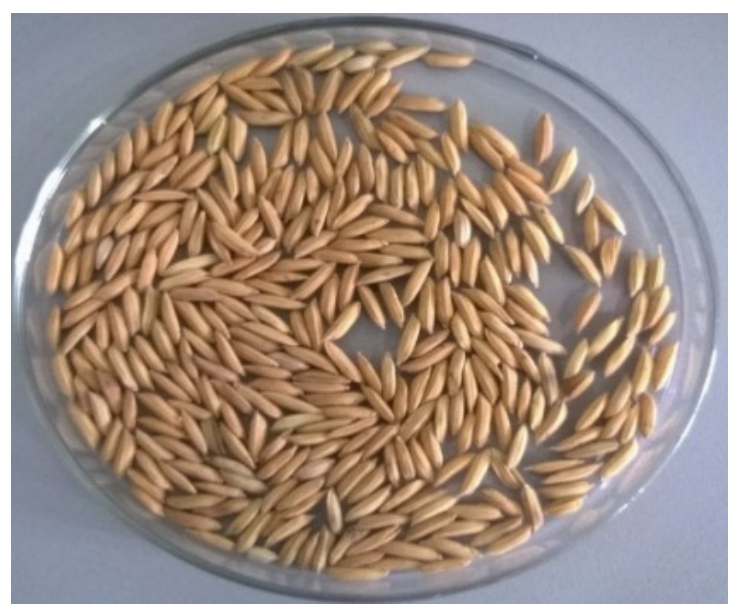

Figure 7. Paddy rice grains before the microwave drying process. 


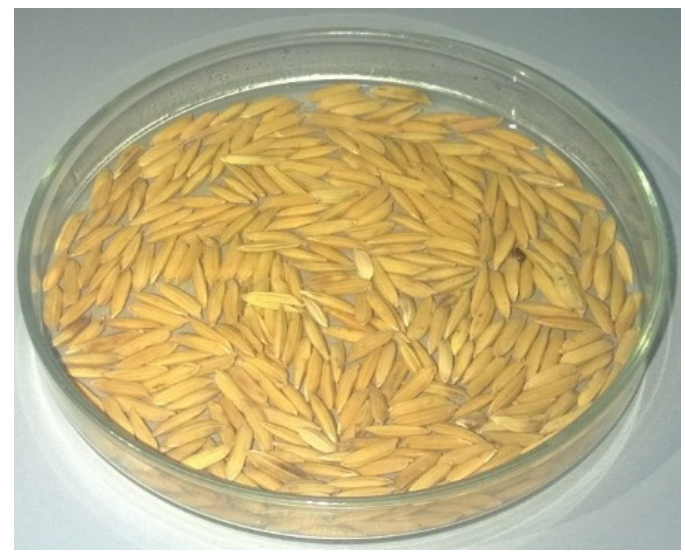

(a) $\mathrm{P}_{\mathrm{n} 1}=6.27 \mathrm{~W} / \mathrm{g}$

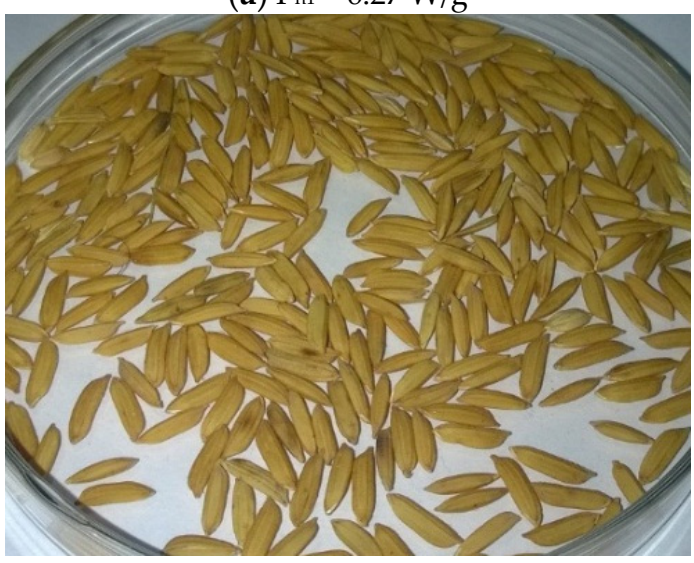

(b) $\mathrm{P}_{\mathrm{n} 2}=14.63 \mathrm{~W} / \mathrm{g}$

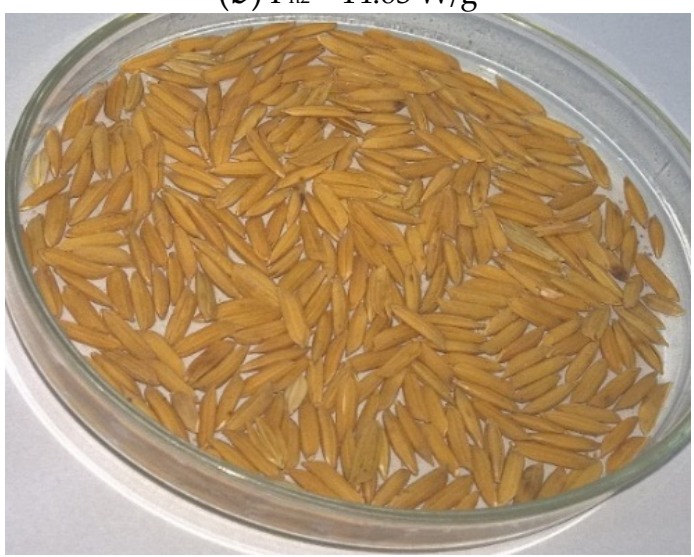

(c) $\mathrm{P}_{\mathrm{n} 3}=22.99 \mathrm{~W} / \mathrm{g}$

Figure 8. Rice grains from samples 1 (a), 2 (b) and 3 (c) after microwave drying process.

Analyzing the rice husks after drying in a microwave oven and oven with forced circulation of hot air, it is possible to highlight some effects of the drying process on the final quality of dry rice grains: appearance of several grains with dark color and the presence of black spots on the husk and extremities, due to the high temperature reached on the surface of the grains in some moments of the drying process, mainly for sample 3, where the surface temperature reached the $130{ }^{\circ} \mathrm{C}$ mark at the instant of time $\mathrm{t}=64 \mathrm{~min}$. Figure 9 shows the rice grain after convective drying process at $60^{\circ} \mathrm{C}$ in oven with forced circulation of hot air. 


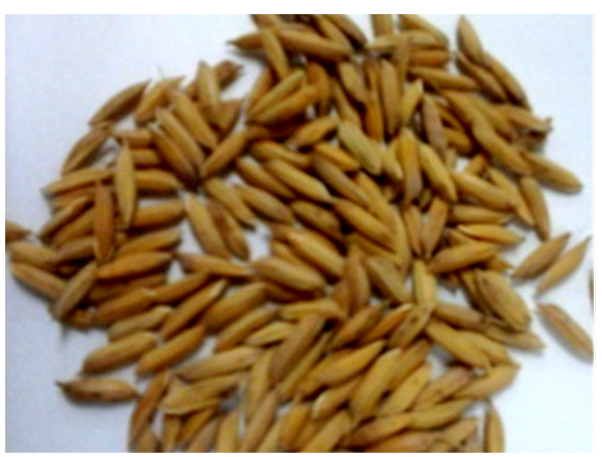

Figure 9. Rice grains after convective drying process at $60{ }^{\circ} \mathrm{C}(\mathrm{Mo}=34.5 \%$ dry basis, $\mathrm{t}=960 \mathrm{~min})$.

Silva [48] reports on the influence of temperature on the final quality of paddy rice grain (BRSMG Conai variety) during the process of pure convective drying, in an oven with forced air circulation. According to the author, an increase in the index of cracks and breaks was detected in the dry rice grains at the drying air temperature of $70{ }^{\circ} \mathrm{C}$ in relation to that obtained in the drying carried out with lower temperatures $\left(40,50\right.$ and $\left.60^{\circ} \mathrm{C}\right)$ and severe cracks affect the germination of the rice grain and reduce the commercial price of this product.

\subsection{Energy Consumption Analysis}

Drying process requires high energy demand. Thus, energy consumption analysis in this process becomes essential. Thus, the sensible, latent and total absorbed energy rates were calculated based on the surface temperature of the rice grain. These thermal energy parameters are given as follows:

$$
\begin{gathered}
\dot{Q}_{S}=m_{s}(1+\bar{M}) c_{p} \frac{d T}{d t} \\
\dot{Q}_{L}=m_{s} h_{f g} \frac{d \bar{M}}{d t} \\
\dot{Q}_{a b s}=\dot{Q}_{S}+\dot{Q}_{L}
\end{gathered}
$$

where $c_{p}$ and $h_{f g}$ are the specific heat and latent heat of water vaporization, respectively, given by:

$$
\begin{gathered}
c_{p}=\left[1.11+0.0488\left(\frac{100 \times \bar{M}}{1+\bar{M}}\right)\right] \times 10^{3}(\mathrm{~J} / \mathrm{kgK}) \\
h_{f g}=\left\{\begin{array}{ll}
2.503 \times 10^{6}-2.386 \times 10^{3} T ; & 0<T \leq 65<{ }^{\circ} \mathrm{C} \\
{\left[7.33 \times 10^{12}-1.60 \times 10^{7}(T+273.15)^{2}\right]^{1 / 2} ;} & 65<T \leq 260^{\circ} \mathrm{C}
\end{array} \quad(\mathrm{J} / \mathrm{kg})\right.
\end{gathered}
$$

In Equation (11), the moisture content is given in decimal dry basis. Table 5 summarize the sensible $\left(\dot{Q}_{S}\right)$, latent $\left(\dot{Q}_{L}\right)$ and total energy $\left(\dot{Q}_{a b s}\right)$ rates absorbed by the paddy rice grains at different elapsed time, at the beginning and final of the drying process in a domestic microwave oven. For a real situation, we state that these values are dependent on the instantaneous average temperature of the rice grain, so, the calculated values are only approximated. 
Table 5. Thermal energy data obtained in the experiments.

\begin{tabular}{ccccccc}
\hline $\mathrm{t}(\min )$ & $\dot{Q}_{S}(\mathrm{~W})$ & $\dot{Q}_{L}(\mathrm{~W})$ & $\dot{Q}_{a b s}(\mathrm{~W})$ & $\dot{Q}_{a b s} / m_{0}(\mathrm{~W} / \mathbf{g}) \boldsymbol{P}_{\text {sup }}(\mathrm{W})$ & $\dot{Q}_{a b s} / \boldsymbol{P}_{\text {sup }}$ \\
\hline 3 & 0.92919 & 1.50487 & 2.43406 & 0.24340 & 71.4 & 0.03409 \\
310 & 0.03143 & 0.00775 & 0.03918 & 0.00392 & 71.4 & 0.00055 \\
3 & 0.18401 & 2.99545 & 3.17946 & 0.31794 & 142.8 & 0.02226 \\
180 & 0.16892 & 0 & 0.16892 & 0.01689 & 142.8 & 0.00118 \\
3 & 1.17076 & 6.00754 & 7.17830 & 0.71783 & 214.2 & 0.03351 \\
110 & 0.15901 & 0.03823 & 0.19724 & 0.01972 & 214.2 & 0.00092 \\
\hline
\end{tabular}

Upon analyzing Table 5, it can be seen that in the initial moments of drying the energy to evaporate water $\left(\dot{Q}_{L}\right)$ is higher that the energy to heating the grain $\left(\dot{Q}_{S}\right)$. However, at the final drying process the sensible energy is higher that the latent energy. The maximum absorbed per incident energy relationship found in the microwave drying process was $3.4 \%$ at the initial stage of drying. These behaviors are very consistent because at the initial moments of the process, the material has high moisture content but at the final process time the rice grain is almost dried (lower moisture content), justifying the weak absorption microwave power (energy performance $0.11 \%$ ).

\section{Conclusions}

In this work, the coupled phenomena of heat and mass transport in agricultural products have been studied, with special attention to drying. Interest in this type of physical problem is justified by the great importance in many industrial applications. This research is focused on microwave drying of paddy rice (rough rice). Based on the results obtained, it can be concluded that:

(a) In the microwave drying of unprocessed rice grains in shell (BRSMG Conai variety), the behavior of the drying rate was shown to be decreasing and independent of the applied microwave power;

(b) The applied microwave power, the temperature inside the grain and the geometry of the product, influence the drying and heating kinetics. The greater the applied microwave power, the greater the rates of moisture removal and the rise in the temperature of the rice grain, and the shorter the drying time;

(c) The time required for the paddy rice grain to reach the average equilibrium moisture content, decreases with an increase in the applied microwave power, from $310 \mathrm{~min}$ to $6.27 \mathrm{~W} / \mathrm{g}, 180 \mathrm{~min}$ to $14.63 \mathrm{~W} / \mathrm{g}$ and $110 \mathrm{~min}$ to $22.99 \mathrm{~W} / \mathrm{g}$;

(d) Microwave powers equal to or greater than $22.99 \mathrm{~W} / \mathrm{g}$ affect the quality of the product, causing discoloration of the rice grain. For this operational condition, the grain reached a maximum temperature of approximately $130{ }^{\circ} \mathrm{C}$ in $64 \mathrm{~min}$ of processing;

(e) Maximum absorbed per incident microwave power relationship found in the microwave drying process is $3.4 \%$ at the initial stage of drying providing that the drying thermal system is improved and optimized, in order to save energy.

Author Contributions: Conceptualization, E.G.S., J.P.G., W.P.S., K.Y.N.P., J.E.F.C., R.O.A., D.D.S.D. and A.G.B.L.; Formal analysis, E.G.S., W.P.S., K.Y.N.P., F.D.R. and A.G.B.L.; Investigation, E.G.S., R.S.G., J.P.G., R.O.A., I.B.S., D.D.S.D. and M.M.C.A.A.; Methodology, E.G.S., K.Y.N.P., F.D.R., J.E.F.C., R.O.A., I.B.S., R.A.A.S., D.D.S.D. and M.M.C.A.A.; Supervision, J.P.G., W.P.S., J.E.F.C., I.B.S. and A.G.B.L.; Visualization, R.S.G. and M.M.C.A.A.; Writing—original draft, E.G.S., J.P.G., R.O.A., R.A.A.S. and A.G.B.L.; Writing一review \& editing, R.S.G., W.P.S., F.D.R., J.E.F.C., I.B.S., R.A.A.S. and A.G.B.L. All authors have read and agreed to the published version of the manuscript.

Funding: This research was funded by CNPq, CAPES, and FINEP (Brazilian 612 research agencies). Institutional Review Board Statement: Not applicable.

Informed Consent Statement: Informed consent was obtained from all subjects involved in the study. 
Data Availability Statement: The data that support the findings of this study are available upon request from the authors.

Acknowledgments: The authors are grateful to the Federal University of Campina Grande (Brazil) and the State University of Paraiba (Brazil) for the research infrastructure and the references cited in the manuscript.

Conflicts of Interest: The authors declare no conflict of interest.

\section{References}

1. Pereira Filho, E.R. Mechanized Systems Coupled to a Microwave Oven for in-Line Mineralization of Samples of Nutritional Interest: Determination of Iron and Cobalt. Master's Thesis, State University of Campinas, Campinas, Brazil, 1999. Available online: http:/ / repositorio.unicamp.br/bitstream/REPOSIP/248571/1/PereiraFilho_EdenirRodrigues_M.pdf (accessed on 5 April 2020). (In Portuguese).

2. Magalhães, R.S.; Lima, R.M.F.; de Souza, H.A. The use of microwaves to determine bauxite moisture. Rem Rev. Esc. Minas 2003, 56, 255-259. (In Portuguese) [CrossRef]

3. Barboza, A.C.; Cruz, C.V.M.S.; Graziani, M.B.; Lorenzetti, M.C.F.; Sabadini, E. Heating in microwave ovens/developing of basic concepts. Química Nova 2001, 24, 901-904. (In Portuguese) [CrossRef]

4. Menezes, R.R.; Souto, P.M.; Kiminami, R. Microwave sintering of ceramics. Part I: Fundamental aspects. Cerâmica 2007, 53, 1-10. [CrossRef]

5. Metaxas, A.C.; Meredith, R.J. Industrial Microwave Heating; Peter Peregrinus Ltd: London, UK, $1983 ;$ ISBN 0906048893.

6. Zhao, X.; Yan, L.; Huang, K. Review of numerical simulation of microwave heating process. In Advances in Induction and Microwave Heating of Mineral and Organic Materials; Grundas, S., Ed.; InTech: Rijeka, Croatia, 2011; pp. 27-48.

7. Hansson, L.; Antti, L. Modeling microwave heating and moisture redistribution in wood. Dry. Technol. 2008, 26, 552-559. [CrossRef]

8. Haghi, A.K.; Amanifard, N. Analysis of heat and mass transfer during microwave drying of food products. Braz. J. Chem. Eng. 2008, 25, 491-501. [CrossRef]

9. Soysal, Y. Mathematical modeling and evaluation of microwave drying kinetics of mint (Mentha spicata L.). J. Appl. Sci. 2005, 5, 1266-1274. [CrossRef]

10. Zhang, M.; Tang, J.; Mujumdar, A.S.; Wang, S. Trends in microwave-related drying of fruits and vegetables. Trends Food Sci. Technol. 2006, 17, 524-534. [CrossRef]

11. Dunaeva, T.; Manturov, A. The phenomenological model microwave drying kinetics of food products. In Proceedings of the 2010 International Kharkov Symposium on Physics and Engineering of Microwaves, Millimeter and Submillimeter Waves (MSMW 2010); Kharkov, Ukraine, 21-26 June 2010, Institute of Electrical and Electronics Engineers (IEEE): Piscataway, NJ, USA, 2010; pp. 1-3. ISBN 9781424479009.

12. Khraisheh, M.A.M.; Cooper, T.J.R.; Magee, T.R.A. Microwave and air drying I. Fundamental considerations and assumptions for the simplified thermal calculations of volumetric power absorption. J. Food Eng. 1997, 33, 207-219. [CrossRef]

13. Maskan, M. Microwave/air and microwave finish drying of banana. J. Food Eng. 2000, 44, 71-78. [CrossRef]

14. Prabhanjan, D.G.; Ramaswamy, H.S.; Raghavan, G.S.V. Microwave-assisted convective air drying of thin layer carrots. J. Food Eng. 1995, 25, 283-293. [CrossRef]

15. Bingol, G.; Pan, Z.; Roberts, J.S.; Devres, Y.O.; Balaban, M.O. Mathematical modeling of microwave-assisted convective heating and drying of grapes. Int. J. Agric. Biol. Eng. 2008, 1, 46-54. [CrossRef]

16. Tang, J.; Feng, H.; Lau, M. Microwave heating in food processing. In Advances in Bioprocessing Engineering; Yang, X.H., Tang, J., Eds.; World Scientific Publishing Co. Pte. Ltd.: Singapore, 2002; Volume 1, pp. 1-43.

17. Zhang, H.; Datta, A.K. Electromagnetics of microwave heating: Magnitude and uniformity of energy absorption in an oven. In Handbook of Microwave Technology for Food Application; Datta, A.K., Anantheswaran, R.C., Eds.; Marcel Dekker AG: New York, NY, USA, 2001; pp. 33-68.

18. Khodifad, B.C.; Dhamsaniya, N.K. Drying of food materials by microwave energy-A review. Int. J. Curr. Microbiol. Appl. Sci. 2020, 9, 1950-1973. [CrossRef]

19. Majetich, G.; Hicks, R. Applications of microwave-accelerated organic synthesis. Radiat. Phys. Chem. 1995, 45, 567-579. [CrossRef]

20. Ren, G.; Chen, F. Drying of American ginseng (Panax quinquefolium roots by microwave-hot air combination. J. Food Eng. 1998, 35, 433-443. [CrossRef]

21. Luz, C.; Baudet, L.; Frandoloso, V. Determination of the water content of rice seeds by microwave drying. Rev. Bras. Sementes 1998, 20, 70-74. (In Portuguese) [CrossRef]

22. Berteli, M.N.; Nogueira, T.L.; Marsaioli, A., Jr. Determination of the temperature distributions in a paddy rice bed during heat treatment with microwaves. Braz. J. Food Technol. 2014, 17, 319-328. (In Portuguese) [CrossRef]

23. Valentini, S.R.T.; Castro, M.F.P.; Almeida, F.H. Determination of moisture content of corn by using a microwave oven. Food Sci. Technol. 1998, 18, 237-240. (In Portuguese) [CrossRef]

24. Torringa, E.; Esveld, E.; Scheewe, I.; van den Berg, R.; Bartels, P. Osmotic dehydration as a pre-treatment before combined microwave-hot-air drying of mushrooms. J. Food Eng. 2001, 49, 185-191. [CrossRef] 
25. Maskan, M. Drying, shrinkage and rehydration characteristics of kiwifruits during hot air and microwave drying. J. Food Eng. 2001, 48, 177-182. [CrossRef]

26. Díaz, G.R.; Martınez-Monzo, J.; Fito, P.; Chiralt, A. Modelling of dehydration-rehydration of orange slices in combined microwave/air drying. Innov. Food Sci. Emerg. Technol. 2003, 4, 203-209. [CrossRef]

27. Fumagalli, F. Pear Drying in Microwave Dryer. Master's Thesis, Federal University of São Carlos, São Carlos, Brazil, 2003. Available online: https:/ / repositorio.ufscar.br/bitstream/handle/ufscar/4056/DissFF.pdf?sequence=1 (accessed on 10 April 2020). (In Portuguese).

28. Monks, L.F.; Costa, C.S.; Soares, G.J.D. Microwave effects on wheat drying (T. aestivum, L.) and flour quality. Aliment. Nutr. Araraquara 2003, 14, 219-224. Available online: https://www.researchgate.net/profile/Cristina_Simoes_Da_Costa/publication/ 49600120_EFEITO_DE_MICROONDAS_NA_SECAGEM_DO_TRIGO_T_aestivum_L_E_NA_QUALIDADE_REOLOGICA_ DA_FARINHA/links/5b1ad47eaca272021cf350c6/EFEITO-DE-MICROONDAS-NA-SECAGEM-DO-TRIGO-T-aestivum (accessed on 2 April 2020). (In Portuguese).

29. Andrés, A.; Bilbao, C.; Fito, P. Drying kinetics of apple cylinders under combined hot air-microwave dehydration. J. Food Eng. 2004, 63, 71-78. [CrossRef]

30. Wang, J.; Xi, Y.S. Drying characteristics and drying quality of carrot using a two-stage microwave process. J. Food Eng. 2005, 68, 505-511. [CrossRef]

31. Srikiatden, J.; Roberts, J.S. Measuring moisture diffusivity of potato and carrot (core and cortex) during convective hot air and isothermal drying. J. Food Eng. 2006, 74, 143-152. [CrossRef]

32. Bouraoui, M.; Richard, P.; Durance, T. Microwave and convective drying of potato slices. J. Food Process Eng. 1994, 17, 353-363. [CrossRef]

33. Ribeiro, R.C. Semi-Dehydrated Tomatoes Obtained by Convective Microwave Drying Preceded by Osmotic Dehydration. Master's Thesis, Federal University of Lavras, Lavras, Brazil, 2013. Available online: http://repositorio.ufla.br/jspui/handle/1/1154 (accessed on 8 April 2020).

34. Celen, S.; Kahveci, K. Microwave drying behaviour of tomato slices. Czech J. Food Sci. 2013, 31, 132-138. [CrossRef]

35. Cunha, M.L.; Canto, M.W.; Marsaioli, A., Jr. Drying pulped coffee cherry beans by means of hot air ond microwaves. Food Sci. Technol. 2003, 23, 381-385. (In Portuguese) [CrossRef]

36. Dadali, G.; Demirhan, E.; Özbek, B. Microwave heat treatment of spinach: Drying kinetics and effective moisture diffusivity. Dry. Technol. 2007, 25, 1703-1712. [CrossRef]

37. Rodriguez, A.; Bruno, E.; Paola, C.; Campañone, L.; Mascheroni, R.H. Experimental study of dehydration processes of raspberries (Rubus Idaeus) with microwave and solar drying. Food Sci. Technol. 2019, 39, 336-343. [CrossRef]

38. Ozcan-Sinir, G.; Ozkan-Karabacak, A.; Tamer, C.E.; Copur, O.U. The effect of hot air, vacuum and microwave drying on drying characteristics, rehydration capacity, color, total phenolic content and antioxidant capacity of Kumquat (Citrus japonica). Food Sci. Technol. 2019, 39, 475-484. [CrossRef]

39. Oomah, B.D.; Liang, J.; Godfrey, D.; Mazza, G. Microwave heating of grapeseed: Effect on oil quality. J. Agric. Food Chem. 1998, 46, 4017-4021. [CrossRef]

40. Cabral, R.A.F.; Telis-Romero, J.; Telis, V.R.N.; Gabas, A.L.; Finzer, J.R.D. Effect of apparent viscosity on fluidized bed drying process parameters of guava pulp. J. Food Eng. 2007, 80, 1096-1106. [CrossRef]

41. Almeida, D.; Rocha, J.; Lages, S.; Coimbra, H. Microwave: General Food Processing; Escola Superior Agrária de Coimbra (ESAC): Coimbra, Portugal, 2010; Available online: http://www.esac.pt/noronha/pga/0910/trabalho_mod2/PGA_microondas_T2 _word.pdf (accessed on 18 April 2020). (In Portuguese)

42. Tang, J.; Resurreccion, F.P., Jr. Electromagnetic basis of microwave heating. In Development of Packaging and Products for Use in Microwave Ovens; Lorence, M.W., Pesheck, P.S., Eds.; Elsevier: Amsterdam, The Netherlands, 2009; pp. 3e-38e.

43. Feng, H.; Yin, Y.; Tang, J. Microwave drying of food and agricultural materials: Basics and heat and mass transfer modeling. Food Eng. Rev. 2012, 4, 89-106. [CrossRef]

44. Laguerre, J.C.; Tauzin, V.; Grenier, E. Hot air and microwave drying of onions: A comparative study. Dry. Technol. 1999, 17, 1471-1480. [CrossRef]

45. Liu, S.; Fukuoka, M.; Sakai, N. A finite element model for simulating temperature distributions in rotating food during microwave heating. J. Food Eng. 2013, 115, 49-62. [CrossRef]

46. Fonseca, J.R.; Brondani, C.; Brondani, R.P.V.; Rangel, P.H.N. Genetic resources. In The Rice Culture in Brazil; Santos, A.B., Stone, L.F., Vieira, N.R.A., Eds.; Embrapa Arroz e Feijão: Santo Antônio de Goiás, Goiás, Brasil, 2006; pp. 257-288. ISBN 85-7437-030-4. (In Portuguese)

47. Amato, G.W.; Elias, M.C.; Gariboldi, F. Parboiling Rice; Editora Ricardo Lenz Ziede: Porto Alegre, Brazil, $2005 ;$ ISBN 8587787411. (In Portuguese)

48. Silva, J.V. Drying of Rough Rice Grains in Fixed Bed: Modeling, Simulation and Experimentation. Ph.D. Thesis, Federal University of Campina Grande, Campina Grande, Brazil, 2016. Available online: http://dspace.sti.ufcg.edu.br:8080/jspui/handle/riufcg/ 951 (accessed on 8 April 2020). (In Portuguese).

49. Walter, M.; Marchezan, E.; Avila, L.A. de Rice: Composition and nutritional characteristics. Ciência Rural 2008, 38, 1184-1192. (In Portuguese) [CrossRef] 
50. Ferrari Filho, E. Methods and Drying Temperatures on the Physical-Chemical and Microbiological Quality of Corn Kernels in Storage. Master's Thesis, Federal University of Rio Grande do Sul, Porto Alegre, Brazil, 2011. Available online: https: / / www.lume.ufrgs.br/bitstream/handle/10183/29535/000776604.pdf?sequence=1 (accessed on 2 April 2020). (In Portuguese).

51. de Alencar, E.R.; Faroni, L.R.D.; Lacerda Filho, A.F.; Peternelli, L.A.; Costa, A.R. Quality of soy bean grains stored under different conditions. Rev. Bras. Eng. Agrícola Ambient. 2009, 13, 606-613. (In Portuguese) [CrossRef]

52. Corrêa, P.C.; Ribeiro, D.M.; Resende, O.; Botelho, F.M. Determination and modeling of physical properties and shrinkage of wheat grains during the drying process. Rev. Bras. Eng. Agrícola Ambient. 2006, 10, 665-670. (In Portuguese) [CrossRef]

53. Oliveira, L.d.C.; Gutkoski, L.C.; Elias, M.C.; Mazzutti, S.; Aosani, E.; Rocha, J.C. da Effect of drying temperature on the quality of white oat grains. Ciência Agrotecnologia 2010, 34, 313-319. (In Portuguese) [CrossRef]

54. Soares, A.A.; Sousa Reis, M.; Cornélio, V.M.O.; Soares, P.C.; Santos, P.G.; Sousa, M.A. BRSMG Conai: Super early rice cultivar for upland crop. Rev. Ceres 2005, 52, 721-727. Available online: http://www.ceres.ufv.br/ojs/index.php/ceres/article/view/3082/9 66 (accessed on 17 April 2020). (In Portuguese).

55. Pólya, G.; Szegö, G. Inequalities for the capacity of a condenser. Am. J. Math. 1945, 67, 1-32. [CrossRef] 